\title{
JMM

\section{PENGARUH KOMPETENSI, MOTIVASI DAN DUKUNGAN ORGANISASI TERHADAP KINERJA PEGAWAI BAGIAN KEUANGAN (Studi Pada Organisasi Perangkat Daerah Se-Kabupaten Lombok Timur)}

\author{
Muhammad Iswadi ${ }^{1}$ \\ Surati ${ }^{2}$ \\ Hermanto $^{3}$ \\ E-mail : bhedoth98@gmail.com
}

ABSTRACT

This research is aimed at analyzing the effect of competence, motivation and organizational support on the performance of financial officers at the Governmental Organization of East Lombok District. This research is an quantitative associative reseach, using primary and secondary data source. The data were collected through questionnaires, interviews and documentation. The population are all 224 employees of Finance Manager at the collection methodused in this research is census method. The data analysis was using multiple regression.

The reseach showed that the competence had positive and significant effect on the performanc, motivation had positive and significant on the performancce, and organizational support had positive and significant on performance. It is suggested that employees improve their competence to be better such as improving the abilityto manage the work to be completed on time and that the organization of the district apparatus in East Lombok continue to provide motivation and passion to the financial officers. In addition, the organizational support provided by the district apparatus organization of East Lombok had been in the category of supporting. Thus each agency that has financial officers needs to maintain such supports as the opportunities for training, the opportunities to be promoted an to keep the work environment of financial officers at the regional apparatus organization in the goverment of East Lombok District. Then it is necessary to improve the performance of employees, to have initiative to finish job without having to wait for command from the boss and to dare to take decisions in accordance with the main tesk and function.

\section{Keywords: Competence, Work Motivation, Organizational Support and Performance}

\section{PENDAHULUAN}

Manusia selalu berperan aktif dalam setiap organisasi karena manusia menjadi perencana, pelaku dan penentu terwujudnya tujuan organisasi. Tujuan tidak mungkin terwujud tanpa peran aktif pegawai meski peralatan yang dimiliki oleh organisasi begitu canggihnya. Tuntutan organisasi untuk memperoleh, mengembangkan dan mempertahankan sumberdaya yang berkualitas semakin mendesak sesuai dengan dinamika lingkungan dan teknologi yang selalu berubah.

1Sekretariat DPRD Kabupaten Lombok Timur

2Program Magister Manajemen Pascasarjana Universitas Mataram 


\section{JMM

Untukitu, setiap organisasi memerlukan strategi untuk dapat mengembangkan sumber daya manusianya salah satu cara yang dapat ditempuh adalah dengan meningkatkan kompetensi dari pegawai itu sendiri (Rivai, 2004). Menurut Wibowo (2007) kompetensi merupakan suatu kemampuan untuk melaksanakan pekerjaan atau tugas yang dilandasi atas keterampilan dan pengetahuan serta didukung oleh sikap kerja yang dituntut oleh pekerjaan tersebut. Setiap organisasi bukan saja mengharapkan pegawai yang kompeten, namun motivasi yang kuat dari para pegawai juga tidak kalah penting dalam organisasi agar pegawai mau bekerja giat dan berkeinginan untuk mencapai hasil yang maksimal.

Menurut Robbins, (2005) motivasi adalah kesediaan individu untuk mengeluarkan upaya yang tinggi untuk mencapai tujuan organisasi. Seorang Pegawai yang memiliki intelegensia cukup tinggi bisa gagal karena kekurangan motivasi. Disamping motivasi dan kompetensi, hal lain yang dapat meningkatkan kinerja pegawai adalah dukungan organisasi.

Menurut Malthisdan Jackson (2003) dukungan organisasi adalah dukungan yang diterima dari organisasinya berupa pelatihan, peralatan, harapan-harapan dan tim kerja yang produktif. Dukungan organisasi dipandang sangat penting bagi perilaku pekerjanya. Organisasi memiliki kewajiban untuk mengembangkan suatu iklim yang mendukung. Dukungan organisasi yang baik, maka akan dapat meningkatkan kinerja dari individu yang berada di dalam organisasi.

Kinerja adalah kesediaan seseorang atau kelompok orang untuk melakukan sesuatu kegiatan dan menyempurnakannya sesuai dengan tanggung jawabnya dengan hasil seperti yang diharapkan (Veithzal, 2010). Kinerja atau prestasi kerja adalah suatu hasil kerja yang dicapai seseorang dalam melaksanakan tugas-tugas yang dibebankan kepadanya yang didasarkan atas kecakapan, pengalaman dan kesungguhan, serta waktu (Hasibuan, 2003). Berdasarkan pengertian kinerja dari beberapa pendapat diatas dapat disimpulkan bahwa kinerja adalah suatu hasil kerja yang dicapai seseorang didalam menjalankan tugastugas yang dibebankan kepadanya dan seberapa banyak mereka dapat memberi kontribusi kepada organisasi. Kinerja juga berarti hasil yang dicapai oleh seseorang, baik kuantitas maupun kualitas dalam suatu organisasi sesuai dengan tanggung jawab yang diberikan kepadanya

Negara adalah juga sebuah organisasi. Untuk menjalankan roda organisasi ini, wilayah-wilayah dibagi menjadi negara bagian atau povinsi. Pemerintah Negara Republik Indonesia membagi wilayah-wilayahnya menjadi Provinsi yang dipimpin oleh seorang Kepala Daerah yang disebut Gubernur dan provinsi-provinsi ini dibagi lagi menjadi Kabupaten/Kota yang dipimpin oleh Kepala Daerah yang disebut Bupati/Walikota. Untuk penyelenggaraan administrasi pemerintahan serta program dan kegiatan pemerintah, Kepala Daerah baik itu Gubernur maupun Bupati/Walikota dibantu oleh perangkat daerah. Perangkat Daerah atau Organisasi Perangkat Daerah (OPD) merupakan organisasi atau lembaga pada Pemerintah Daerah yang bertanggung jawab kepada Kepala Daerah dalam rangka penyelenggaraan pemerintahan di daerah. Perangkat Daerah dibentuk oleh masing-masing Daerah berdasarkan pertimbangan karakteristik, potensi dan kebutuhan Daerah.

Pembentukan perangkat daerah semata-mata didasarkan pada pertimbangan rasional untuk melaksanakan urusan pemerintahan yang menjadi kewenangan daerah secara efektif dan efisien. Dalam setiap organisasi perangkat Daerah di Kabupaten Lombok Timur terdapat Pegawai Pengelola Keuangan Daerah yang terdiri dari Kepala Sub Bagian 


\section{JMM

Keuangan, Bendahara Pengeluaran, Bendahara Penerimaan (untuk OPD yang mengelola Penerimaan Asli Daerah) dan Pembantu Bendahara. Tugas Aparatur Pengelola Keuangan Daerah di masing-masing Organisasi Perangkat Daerah adalah melaksanakan pengelolaan urusan keuangan

Di dalam pelaksanaan APBD dalam rangka mempertanggungjawabkan pelaksanaan dari pengurusan keuangan yang dilaksanakan oleh Aparatur Pengelola Keuangan Daerah, masih belum seperti yang diharapkan. Terdapat beberapa fenomena yang terlihat seperti masih terdapatnya kesalahan-kesalahan pencatatan pada buku kas umum, terlambatnya pengiriman SPJ yang menyebabkan kelancaran penyediaan dana pada unit kerja sering terhambat, penatausahaan pada bagian keuangan tidak dapat tepat waktu dan pengendalian keuangan tidak dapat dilaksanakan dengan baik, karena data keuangan belum dapat siap setiap saat dibutuhkan. Berdasarkan pengamatan awal, hal ini terjadi karena kurangnya keterampilan serta kemampuan pegawai pengelola keuangan daerah di masing-masing OPD pada Pemerintah Kabupaten Lombok Timur karena OPD sangat jarang mengadakan pelatihan-pelatihan dan tidak memberikan pegawai pengelola keuangan daerah untuk menempuh pendidikan di tingkat lanjut, Selain itu juga, masalahmasalah yang terjadi pada pegawai pengelola keuangan daerah di masing-masing OPD pada Pemerintah kabupaten Lombok Timur adalah karena kurangnya diberi penghargaan serta apresiasi, baik dari atasan maupun organisasinya masing-masing selain itu juga dari sisi pendidikan, pegawai pengelola keuangan daerah sangat sedikit yang berasal dari sarjana ekonomi sehingga terjadi gap pengetahuan antara apa yang didapatkan pada masa kuliah dan pekerjaan yang harus dijalaninya, selain itu juga dari sisi pelatihan masih sangat kurang untuk dilakukan, pelatihan yang dilakukan masih jarang yang berkaitan dengan pengelolaan keuangan daerah sehingga hal ini tidak meningkatkan kinerja pegawai pengelola keuangan daerah di masing-masing OPD pada Pemerintah Kabupaten Lombok Timur. Dengan adanya fenomena seperti yang dikemukakan diatas dan masih banyaknya terjadi perbedaan hasil penelitian atau adanya research gap (celahpenelitian), penulis tertarik untuk melakukan penelitian yang berkaitan dengan kompetensi, motivasi, dukungan organisasi dan kinerja.

Adapun research gap atau celah penelitian dari hasil beberapa penelitian terdahulu terkait kompetensi, motivasi, dukungan organisasi dan kinerja seperti yang dilakukan oleh Sutrischastini dan Riyanto (2015) menunjukan bahwa motivasi berpengruh positif signifikan terhadap kinerja pegawai Kantor Sekretariat Daerah Kabupaten Gunung kidul. Sementara itu, penelitian yang dilakukan oleh Ogbogu (2017) menemukan bahwa motivasi tidak berpengaruh terhadap kinerja pegawai. Selanjutnya penelitian yang dilakukan oleh Lipu (2017) menunjukan bahwa dukungan organisasi berpengaruh terhadap kinerja pegawai. Sementara itu, penelitian yang dilakukan oleh Amirulloh et al (2016) menemukan bahwa dukungan organisasi tidak berpengaruh terhadap kinerja.

Sedangkan penelitian yang dilakukan oleh Untari dan Wahyuanti (2014) menunjukan bahwa variabel kompetensi mempunyai pengaruh signifikan terhadap kinerja pegawai. Sementara itu, penelitian yang dilakukan oleh Jumaking et al (2017) menemukan bahwa kompetensi tidak berpengaruh terhadap kinerja pegawai. Dari beberapa penelitian terdahulu yang dikemukakan diatas masih banyaknya terjadi perbedaan hasil penelitian, sehingga penulis tertarik untuk melakukan penelitian yang berkaitan dengan kompetensi, motivasi, dukungan organisasi dan kinerja. 


\section{JMM

\section{METODE PENELITIAN}

Sesuai dengan perumusan masalah dan tujuan yang dilakukan, maka jenis penelitian yang digunakan dalam penelitian ini adalah penelitian kuantitati fasosiatif.

Populasi dalam penelitian ini adalah semua Pegawai Bagian Keuangan di Organisasi Perangkat Daerah Kabupaten Lombok Timur sehingga berjumlah 224 orang. Metode pengumpulan data yang digunakan dalam penelitian ini adalah metode sensus. Dengan demikian sampel yang digunakan dalam penelitian ini berjumlah 224 responden. Teknik pengumpulan data yang digunakan dalam penelitian ini adalah teknik angket, wawancara dan dokumentasi. Sedangkan alat pengumpulan data dalam penelitian ini adalah dengan menggunakan kuesioner (daftar pertanyaan).

\subsection{Karakteristik Responden}

\section{HASIL PENELITIAN}

Pada penelitian ini karakteristik responden dibedakan berdasarkan jenis kelamin, usia dan pendidikan terakhir. Berdasarkan jenis kelamin terdapat responden yang berjenis kelamin laki-laki berjumlah 128 orang dengan persentase 57,1 persen dan responden yang berjenis kelamin perempuan berjumlah 96 orang dengan persentase 42,9 persen. Berdasarkan usia diketahui bahwa jumlah responden yang berusia 20-30 tahun berjumlah 46 orang dengan persentase 20,6 persen, yang berusia 31-40 tahun berjumlah 86 orang dengan persentase 38,4 persen. Kemudian yang berjumlah 41-50 tahun berjumlah 67 orang dengan persentase 29,9 persen dan yang berusia 51-60 tahun berjumlah 25 orang dengan persentase 11,1 persen. Sedangkan berdasarkan pendidikan terakhir dapat diketahui bahwa responden yang jenjang pendidikan terakhirnya SMA berjumlah 10 pegawai dengan persentase 4,5 persen. Kemudian responden yang jenjang pendidikan terakhirnya diploma berjumlah 72 pegawai dengan persentase 32,1 persen dan yang jenjang pendidikan paling dominan ialah S1 yang berjumlah 98 pegawai dengan persentase 43,8 persen. Sedangkan untuk jenjang S2 yaitu sebanyak 44 pegawai dengan persentase 19,6 persen

Hasil analisis regresi berganda untuk meramalkan variasi kinerja pegawai jika dipengaruhi oleh kompetensi, motivasi dan dukungan organisasi disajikan dalam tabel sebagai berikut

\section{Tabel 1.1 Hasil Regresi Berganda}

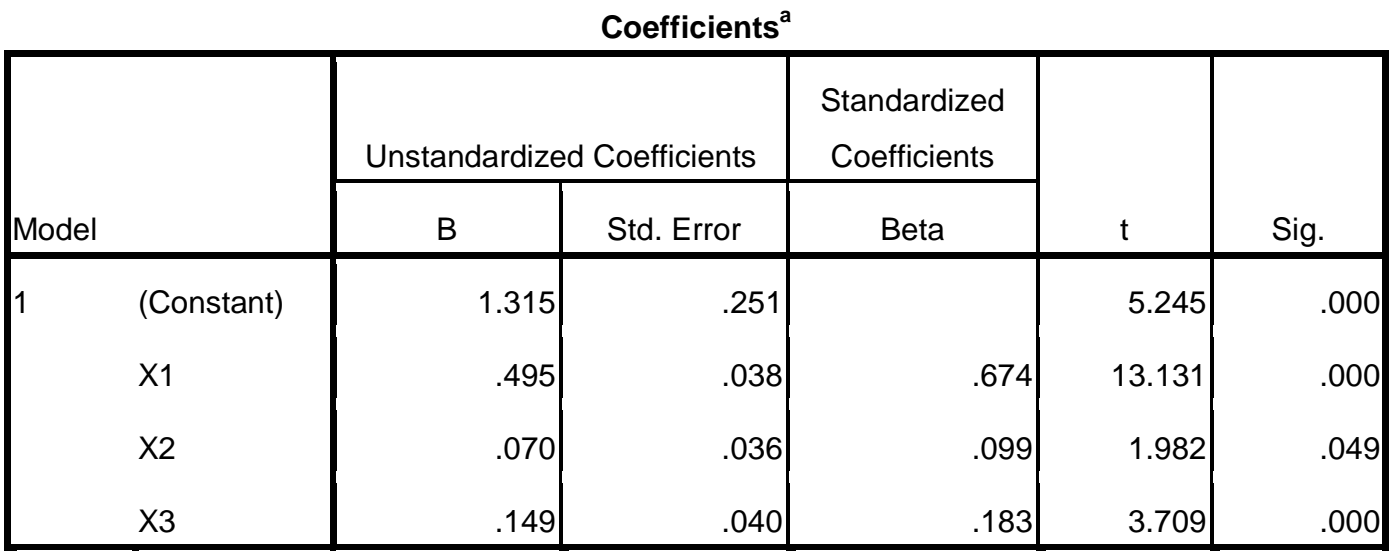

a. Dependent Variable: $Y$

Sumber: Data Primer yang diolah 


\section{JMM \\ UNRAM

Berdasarkan hasil analisis regresi berganda pada tabel 1.1, diketahui nilai konstanta 1.315, nilai koefisien regresi variabel kompetensi 0.495 , nilai koefisien regresi variabel motivasi 0.070 dan nilai koefisien regresi variabel dukungan organisasi 0.149 , maka persamaan regresi bergandanya adalah sebagai berikut :

Dimana :

$$
\begin{gathered}
Y=a+b_{1} X_{1}+b_{2} X_{2}+b_{3} X_{3}+e \\
Y=1.315+0.495 X_{1}+0.070 X_{2}+0.149 X_{3}+e
\end{gathered}
$$

Y : Kinerja

$\mathrm{X}_{1}$ : Kompetensi

$\mathrm{X}_{2}$ : Motivasi

$\mathrm{X}_{3}$ : Dukungan Organisasi

a : Konstanta

$b_{1}$ : Koefisien regresi Kompetensi

$\mathrm{b}_{2}$ :Koefisien regresi Motivasi

$\mathrm{b}_{3}$ : Koefisien regresi Dukungan Organisasi

e : Error

\subsection{Uji Multikolinieritas}

Uji multikolonieritas dilakukan dengan menganalisis matrik korelasi variabelvariabel independent. Berikut ini hasil uji multikolineiaritas yaitu:

Tabel 1.2 Hasil Uji Multikolinieritas

\begin{tabular}{|c|c|c|c|c|c|c|c|}
\hline \multirow[b]{2}{*}{ Model } & \multicolumn{2}{|c|}{$\begin{array}{c}\text { Unstandardized } \\
\text { Coefficients }\end{array}$} & \multirow{2}{*}{$\begin{array}{c}\begin{array}{c}\text { Standardize } \\
\mathrm{d} \\
\text { Coefficients }\end{array} \\
\text { Beta }\end{array}$} & \multirow[b]{2}{*}{$\mathrm{T}$} & \multirow[b]{2}{*}{ Sig. } & \multicolumn{2}{|c|}{$\begin{array}{c}\text { Collinearity } \\
\text { Statistics }\end{array}$} \\
\hline & B & Std. Error & & & & $\begin{array}{c}\text { Toleranc } \\
\mathrm{e}\end{array}$ & VIF \\
\hline $\begin{array}{ll}1 & \text { (Constan } \\
& \mathrm{t})\end{array}$ & 1.315 & .251 & & 5.245 & .000 & & \\
\hline X1 & .495 & .038 & .674 & 13.131 & .000 & .889 & 1.124 \\
\hline $\mathrm{X} 2$ & .070 & .036 & .099 & 1.952 & .052 & .916 & 1.091 \\
\hline $\mathrm{X} 3$ & .149 & .040 & .183 & 3.709 & .000 & .961 & 1.040 \\
\hline
\end{tabular}

\section{Coefficients ${ }^{\mathrm{a}}$}

a. Dependent Variable: $Y$

Sumber: Data primer yang diolah

Dari Tabel di atas, dapat dilihat bahwa hasil nilai tolerance masing-masing variabel dalam penelitian ini lebih besar dari 0,10. Oleh karena itu, dapat dikatakan tidak terjadi multikolonieritas antar variabel independent dalam penelitian ini 


\section{JMM

\subsection{Uji Heteroskedastisitas}

Hubungan heteroskedastisitas terjadi jika pada scatterplot titik-titik hasil pengolahan dan antara ZPRED dan SRESID menyebar dibawah maupun diatas titik origin (angka 0) pada sumbu $\mathrm{Y}$ dan tidak mempunyai pola yang teratur. Hasil uji heteroskedastisitas ditunjukkan pada gambar 1.3

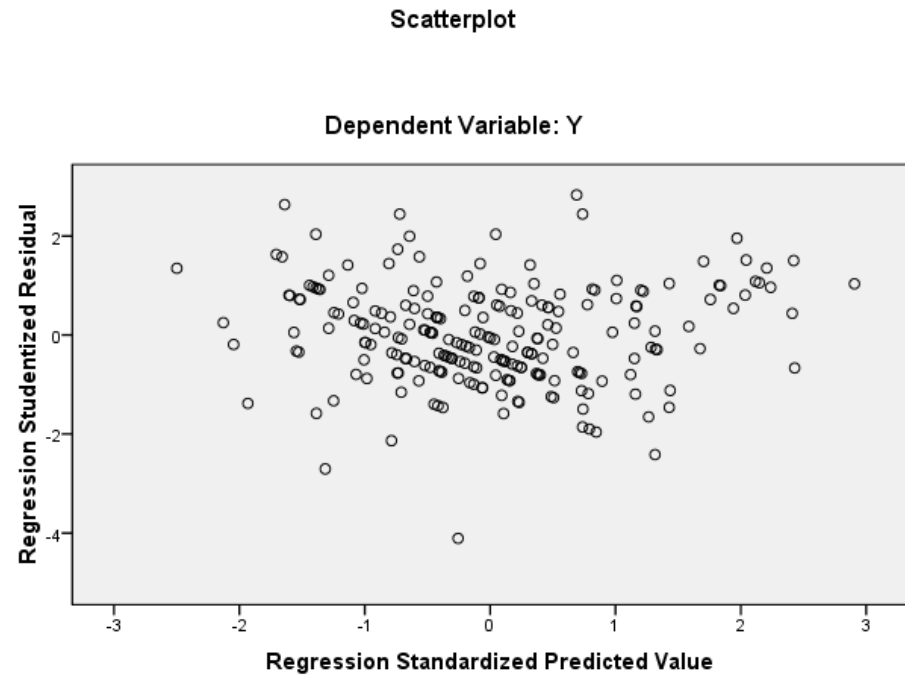

Gambar 1.3 : Hasil Uji Heteroskedastisitas Kinerja

Sumber : Data primer diolah, 2017

Berdasarkan gambar 1.3 , terlihat bahwa titik-titiknya menyebar secara acak, tidak membentuk sebuah pola tertentu yang jelas, tersebar baik diatas maupun angka 0 pada sumbu Y. Hal ini berarti tidak terjadi heteroskedastisitas pada model regresi, sehingga bisa disimpulkan bahwa model regresi layak dipergunakan untuk memprediksi variabel kinerja pegawai bagian keuangan di organisasi perangkat daerah Kabupaten Lombok Timur berdasarkan masukan variabel kompetensi, motivasi dan dukungan organisasi

\subsection{Uji Hipotesis}

\subsubsection{Uji Statistik $t$}

Pembuktian terhadap hipotesis yang telah disusun dilakukan dengan menggunakan perhitungan regresi melalui bantuan program SPSS versi 16.0 for windows. Arah dan kekuatan hubungan antara variabel bebas kompetensi, motivasi dan dukungan organisasi dengan variabel terikat kinerja dalam penelitian ini dapat dilihat dari nilai $t_{\text {hitung }}$ dan tingkat siginifikansinya, sebagaimana disajikan pada tabel berikut: 


\section{$J M M$ UNRAM \\ JURNAL MAGISTER MANAJEMEN \\ UNIVERSITAS MATARAM \\ Nopember 2017}

Tabel 1.4 Hasil Regresi Berganda

Coefficients ${ }^{\mathrm{a}}$

\begin{tabular}{|c|c|c|c|c|c|c|}
\hline \multirow{2}{*}{\multicolumn{2}{|c|}{ Model }} & \multicolumn{2}{|c|}{ Unstandardized Coefficients } & \multirow{2}{*}{$\begin{array}{c}\begin{array}{c}\text { Standardized } \\
\text { Coefficients }\end{array} \\
\text { Beta }\end{array}$} & \multirow[b]{2}{*}{$\mathrm{t}$} & \multirow[b]{2}{*}{ Sig. } \\
\hline & & B & Std. Error & & & \\
\hline 1 & ) (Constant & 1.315 & .251 & & 5.245 & .000 \\
\hline & $\mathrm{X} 1$ & .495 & .038 & .674 & 13.131 & .000 \\
\hline & $\mathrm{X} 2$ & .070 & .036 & .099 & 1.982 & .049 \\
\hline & X3 & .149 & .040 & .183 & 3.709 & .000 \\
\hline
\end{tabular}

a. Dependent Variable: $Y$

Hasil perhitungan regresi berganda secara untuk membuktikan hipotesis yang telah disusun sebagaimana data pada tabel diatas dapat dijelaskan sebagai berikut:

1. Dengan menggunakan tingkat keyakinan $95 \%$, dimana $a=5 \%, \mathrm{df}$ (degree of freedom) $=$ $\mathrm{n}-1-\mathrm{k}=224-1-4=219$, sehingga diperoleh hasil untuk $\mathrm{t}$ tabel sebesar 1,970. Sehingga karena $t$ hitung kompetensi $>\mathrm{t}$ tabel $(13.131>1.970)$ maka dapat disimpulkan bahwa terdapat pengaruh yang signifikan dari kompetensi terhadap kinerja pegawai bagian keuangan di organisasi perangkat daerah Kabupaten Lombok Timur. Nilai signifikansi variabel kompetensi adalah sebesar 0,000 dimana nilai signifikansi ini lebih kecil dari nilai signifikansi yang telah ditentukan sebesar $5 \%(0,05)$, sehingga dapat disimpulkan bahwa kompetensi pegawai bagian keuangan di organisasi perangkat daerah Kabupaten Lombok Timur berpengaruh positif dan signifikan terhadap kinerja pegawai bagian keuangan di organisasi perangkat daerah Kabupaten Lombok Timur. Hal ini berarti bahwa jika semakin tinggi kompetensi yang dimiliki oleh pegawai bagian keuangan di organisasi perangkat daerah Kabupaten Lombok Timur, maka akan menyebabkan meningkatnya kinerja dari pegawai bagian keuangan di organisasi perangkat daerah Kabupaten Lombok Timur dan sebaliknya jika semakin rendah kompetensi yang dimiliki oleh pegawai bagian keuangan di organisasi perangkat daerah Kabupaten Lombok Timur, maka akan menyebabkan menurunnya kinerja dari pegawai bagian keuangan di organisasi perangkat daerah Kabupaten Lombok Timur.

2. Dengan menggunakan tingkat keyakinan $95 \%$, dimana $a=5 \%$, df (degree of freedom) $=$ $\mathrm{n}-1-\mathrm{k}=224-1-4=219$, sehingga diperoleh hasil untuk $\mathrm{t}$ tabel sebesar 1,970. Sehingga karena $\mathrm{t}$ hitung motivasi $>\mathrm{t}$ tabel $(1.982>1.970)$ maka dapat disimpulkan bahwa terdapat pengaruh yang signifikan dari motivasi terhadap kinerja pegawai bagian keuangan di organisasi perangkat daerah Kabupaten Lombok Timur. Nilai signifikansi variabel motivasi adalah sebesar 0,044 dimana nilai signifikansi ini lebih kecil dari nilai signifikansi yang telah ditentukan sebesar $5 \%(0,05)$, sehingga dapat disimpulkan bahwa motivasi berpengaruh positif dan signifikan terhadap kinerja pegawai bagian keuangan di organisasi perangkat daerah Kabupaten Lombok Timur. Hal ini berarti bahwa jika semakin tinggi motivasi dari pegawai bagian keuangan di organisasi perangkat daerah Kabupaten Lombok Timur maka akan menyebabkan meningkatnya kinerja dari pegawai bagian keuangan di organisasi perangkat daerah Kabupaten Lombok Timur dan sebaliknya jika semakin rendah motivasi pegawai bagian keuangan di organisasi perangkat daerah Kabupaten Lombok Timur, maka akan menyebabkan menurunnya kinerja dari pegawai bagian keuangan di organisasi perangkat daerah Kabupaten Lombok Timur 


\section{$J M M$ UNRAM

3. Dengan menggunakan tingkat keyakinan 95\%, dimana $\alpha=5 \%, \mathrm{df}$ (degree of freedom) $=$ $\mathrm{n}-1-\mathrm{k}=224-1-4=219$, sehingga diperoleh hasil untuk $\mathrm{t}$ tabel sebesar 1,970. Sehingga karena $t$ hitung dukungan organisasi $>t$ tabel $(3.709>1.970)$ maka dapat disimpulkan bahwa terdapat pengaruh yang signifikan dari dukungan organisasi terhadap kinerja pegawai bagian keuangan di organisasi perangkat daerah Kabupaten Lombok Timur. Nilai signifikansi variabel dukungan organisasi adalah sebesar 0,000 dimana nilai signifikansi ini lebih kecil dari nilai signifikansi yang telah ditentukan sebesar $5 \%(0,05)$, sehingga dapat disimpulkan bahwa dukungan organisasi yang diberikan bagi pegawai bagian keuangan di organisasi perangkat daerah Kabupaten Lombok Timur berpengaruh positif dan signifikan terhadap kinerja pegawai bagian keuangan di organisasi perangkat daerah Kabupaten Lombok Timur. Hal ini berarti bahwa jika dukungan organisasi semakin tinggi motivasi yang dimiliki oleh pegawai bagian keuangan di organisasi perangkat daerah Kabupaten Lombok Timur, maka akan menyebabkan meningkatnya kinerja dari pegawai bagian keuangan di organisasi perangkat daerah Kabupaten Lombok Timur dan sebaliknya jika semakin rendah motivasi yang dimiliki oleh pegawai bagian keuangan di organisasi perangkat daerah Kabupaten Lombok Timur, maka akan menyebabkan menurunnya kinerja dari pegawai bagian keuangan di organisasi perangkat daerah Kabupaten Lombok Timur

Berdasarkan hasil analisis pengujian hipotesis diatas, dapat dibuat ringkasan seperti pada tabeldi bawah ini:

Tabel 1.5 Ringkasan Pengujian Hipotesis

\begin{tabular}{|c|l|c|c|}
\hline Hipotesis & \multicolumn{1}{|c|}{ Pernyataan Hipotesis } & Signifikansi & Keputusan \\
\hline 1. & $\begin{array}{l}\text { Diduga kompetensi berpengaruh positif } \\
\text { dan signifikan terhadap kinerja pegawai } \\
\text { bagian keuangan di organisasi perangkat } \\
\text { daerah Kabupaten Lombok Timur }\end{array}$ & 0,000 & Diterima \\
\hline 2. & $\begin{array}{l}\text { Diduga motivasi berpengaruh positif dan } \\
\text { signifikan terhadap kinerja pegawai } \\
\text { bagian keuangan di organisasi perangkat } \\
\text { daerah Kabupaten Lombok Timur }\end{array}$ & 0,049 & Diterima \\
\hline 3. & $\begin{array}{l}\text { Diduga dukungan organisasi } \\
\text { berpengaruh positif dan signifikan } \\
\text { terhadap kinerja pegawai bagian } \\
\text { keuangan di organisasi perangkat daerah } \\
\text { Kabupaten Lombok Timur }\end{array}$ & 0,000 & Diterima \\
\hline
\end{tabular}

\subsubsection{Uji Koefisien Determinasi $\left(R^{2}\right)$}

Koefisien determinasi $\left(\mathrm{R}^{2}\right)$ pada intinya mengukur seberapa jauh kemampuan model dalam menerangkan variasi variabel terikat(Kuncoro, 2007 :84). .Hasil perhitungan koefisien determinasi $\left(\mathrm{R}^{2}\right)$ variabel kompetensi, motivasi dan dukungan organisasi terhadap kinerja dalam penelitian ini disajikan pada tabel 1.6 
Tabel 4.5 Hasil Uji Koefisien Determinasi $\left(\mathbf{R}^{2}\right)$

Model Summary

\begin{tabular}{|l|r|r|r|c|}
\hline Model & \multicolumn{1}{|c|}{$\mathrm{R}$} & $\mathrm{R}$ Square & \multicolumn{1}{c|}{$\begin{array}{c}\text { Adjusted R } \\
\text { Square }\end{array}$} & $\begin{array}{c}\text { Std. Error of the } \\
\text { Estimate }\end{array}$ \\
\hline 1 & $.696^{\mathrm{a}}$ & .485 & .478 & .23844 \\
\hline
\end{tabular}

a. Predictors: (Constant), X3, X2, X1

Sumber: Data Primer yang diolah

Pada tabel 4.5 terlihat bahwa nilai AdjustedR Square (koefisien determinasi) sebesar 0.478 $(47.8 \%)$. Ini berarti bahwa pengaruh ketiga variabel bebas yakni Kompetensi (X1), Motivasi (X2), Dukungan Organisasi (X3) terhadap variabel terikat yakni Kinerja (Y) adalah sebesar 47.8\%, sedangkan 52,2\% (100\% - 48,3\%) dipengaruhi oleh variabel lain diluar model ini. Beberapa variabel lainnya yang mempengaruhi kinerja seperti kompensasi, kepuasan kerja, karakteristik pekerjaan, usia, tingkat pendidikan, lingkungan kerja dan pengembangan karir.

\subsection{PEMBAHASAN}

\subsubsection{Pengaruh Kompetensi Terhadap Kinerja Pegawai Bagian Keuangan Di Organisasi} Perangkat Daerah Kabupaten Lombok Timur

Berdasarkan hasil analisis diketahui bahwa kompetensi berpengaruh positif dan signifikan terhadap kinerja pegawai bagian keuangan di organisasi perangkat daerah Kabupaten Lombok Timur, sehingga hipotesis 1 yang menyatakan "Diduga kompetensi berpengaruh positif dan signifikan terhadap kinerja pegawai bagian keuangan di organisasi perangkat daerah Kabupaten Lombok Timur" diterima.

Hasil penelitian ini menunjukkan bahwa semakin tinggi kompetensi yang dimiliki pegawai bagian keuangan di organisasi perangkat daerah Kabupaten Lombok Timur maka akan semakin baik kinerja dari pegawai bagian keuangan di organisasi perangkat daerah Kabupaten Lombok Timur. Berdasarkan data empiris pada penelitian ini, sebanyak 86 orang atau sebesar 38,6 persen berada pada rentang usia 31 hingga 40 tahun, hal ini menunjukkan bahwa pegawai bagian keuangan masih tergolong berada pada usia muda dan produktif sehingga faktanya mereka masih bersemangat untuk menambah pengetahuan, kemampuan dan keterampilan yang dimilikinya. Hasil penelitian ini juga menunjukkan bahwa pegawai bagian keuangan di organisasi perangkat daerah telah memiliki kemampuan dan keterampilan untuk mengerjakan pekerjaannya secara efektif dan efisien. Menurut Hadi (2007) bahwa ketika seorang pegawai memiliki kompetensi yang tinggi atau berkompeten dalam pekerjannnya, maka ia akan mengerjakan pekerjaan tersebut dengan benar dan meminimalkan kesalahan. Tentunya hal ini akan berakibat kepada kinerja yang ditunjukkan semakin baik.

\subsubsection{Pengaruh Motivasi Terhadap Kinerja Pegawai Bagian Keuangan Di Organisasi Perangkat Daerah Kabupaten Lombok Timur}

Berdasarkan hasil analisis diketahui bahwa motivasi berpengaruh positif dan signifikan terhadap kinerja pegawai bagian keuangan organisasi perangkat daerah Kabupaten Lombok Timut, sehingga hipotesis 2 yang menyatakan "Diduga motivasi berpengaruh positif dan signifikan terhadap kinerja pegawai bagian keuangan di organisasi perangkat daerah Kabupaten Lombok Timur" diterima.

Hasil penelitian ini sejalan dengan penelitian yang dilakukan oleh Arie (2007) dan Hadi (2007). Berdasarkan tanggapan responden terkait dengan motivasi, pegawai bagian keuangan di organisasi perangkat daerah memiliki motivasi yang tinggi untuk dapat 
mencapai tujuan organisasinya. Selain itu juga, karakteristik responden berdasarkan usia, rentang usia pegawai bagian keuangan di organisasi perangkat daerah terbanyak berada pada rentang 31 hingga 40 tahun, hal ini mengindikasikan bahwa keinginan mereka untuk berprestasi masih sangat besar.

Fakta di lapangan menemukan bahwa, banyak dari pegawai bagian keuangan termotivasi untuk menjadi pimpinan-pimpinan di organisasi perangkat daerah terlebih dengan adanya sistem lelang jabatan yang memungkinkan siapapun untuk menduduki jabatan tertentu ketika memiliki kinerja yang baik dan memenuhi kriteria membuat mereka termotivasi untuk selalu berkinerja baik, sehingga hal ini menjadi salah satu pendorong atau pemicu bagi mereka untuk memberikan atau menujukkan kinerja terbaiknya

\subsubsection{Pengaruh Dukungan Organisasi Terhadap Kinerja Pegawai Bagian Keuangan Di Organisasi Perangkat Daerah Kabupaten Lombok Timur}

Berdasarkan hasil analisis diketahui bahwa dukungan organisasi berpengaruh positif dan signifikan terhadap kinerja pegawai bagian keuangan organisasi perangkat daerah Kabupaten Lombok Timur, sehingga hipotesis 3 yang menyatakan "Diduga dukungan organisasi berpengaruh positif dan signifikan terhadap kinerja pegawai bagian keuangan di organisasi perangkat daerah Kabupaten Lombok Timur" diterima.

Berdasarkan tanggapan responden terkait dukungan organisasi, para pegawai bagian keuangan di organisasi perangkat daerah memiliki tanggapan bahwa organisasinya tempat bekerja saat ini mendukung mereka untuk dapat bekerja lebih baik dan menunjukkan kinerja terbaiknya. Hal ini ditunjukkan dari 4 indikator yang diberikan, seperti indikator penghargaan, para pegawai bagian keuangan di organisasi perangkat daerah memiliki tanggapan bahwa organisasi perangkat daerah telah memberikan dukungan seperti memberikan penghargaan atas pencapaian kerja para pegawai, lalu pada indikator pengembangan, tanggapan pegawai bagian keuangan di organisasi perangkat daerah memiliki tanggapan bahwa organisasi perangkat daerah telah memberikan dukungan dalam bentuk memberikan kesempatan promosi untuk pegawai dengan memperhatikan kemampuan yang dimiliki oleh pegawai itu sendiri, lalu indikator berikutnya yakni kondisi kerja tanggapan pegawai bagian keuangan di organisasi perangkat daerah memiliki tanggapan bahwa organisasi perangkat daerah telah memberikan dukungan dalam bentuk lingkungan kerja baik fisik maupun non-fisik, pada lingkungan kerja fisik kantor-kantor di lingkungan organisasi perangkat daerah Kabupaten Lombok Timur telah memiliki kantor yang nyaman untuk bekerja, terlebih pada bagian keuangan telah memiliki ruangan sendiri sehingga para pegawai bagian keuangan tersebut dapat fokus untuk bekerja, di sisi lain pada lingkungan kerja non-fisik, pada tiap-tiap hari jumat diadakan kegiatan imtaq pagi, hal ini membuat para pegawai lebih akrab satu sama lain dan persaudaraan menjadi lebih erat. 


\section{$J M M$

\section{KESIMPULAN DAN SARAN}

\subsection{Kesimpulan}

Berdasarkan hasil danpenelitian di atas, maka kesimpulan yang dapat diberikan dari penelitian ini adalah sebagai berikut:

1. Kompetensi memiliki pengaruh positif dan sigifikan terhadap kinerja, artinya semakin tinggi kompetensi yang dimiliki pegawai bagian keuangan, maka akan semakin baik kinerja dari pegawai bagian keuangan di organisasi perangkat daerah Kabupaten Lombok Timur.

2. Motivasi memiliki pengaruh positif dan signifikan terhadap kinerja, artinya semakin tinggi motivasi dari pegawai bagian keuangan, maka akan meningkatkan kinerja dari pegawai bagian keuangan di organisasi perangkat daerah Kabupaten Lombok Timur.

3. Dukungan organisasi memiliki pengaruh positif dan sigifikan terhadap kinerja, artinya semakin baik dukungan organisasi yang diberikan kepada pegawai bagian keuangan, maka akan meningkatkan kinerja pegawai bagian keuangan di organisasi perangkat daerah Kabupaten Lombok Timur.

4. Berdasarkan nilai koefisien determinasi diketahui bahwa pengaruh kompetensi, motivasi dan dukungan organisasi terhadap kinerja pegawai bagian keuangan sebesar 48,3 persen, sedangkan 51,7 persen dipengaruhi oleh faktor lain di luar model.

\subsection{Saran}

Adapun beberapa saran yang dapat direkomendasikan berdasarkan hasil penelitian adalah sebagai berikut :

1. Kompetensi yang dimiliki oleh para pegawai bagian keuangan di organisasi perangkat daerah telah berada pada kategori kompeten, namun demikian para pegawai harus meningkatkan kembali kompetensinya agar menjadi sangat kompeten, seperti meningkatkan kemampuan dalam mengelola dan mengatur pekerjaan agar dapat selesai tepat waktu, meningkatkan kemampuan untuk menyelesaikan tugas tanpa terjadi kesalahan, memiliki rasa bahwa tugas yang diemban untuk kebaikan organisasi, mampu menempatkan diri sebagai bagian dari sistem kerja yang ada, meningkatkan kemampuan untuk mendapatkan informasi dengan baik dari Job Desc hingga dapat memahami pekerjaan dengan baik, meningkatkan pengetahuan segala kegiatan teknis terkait dengan lingkup pekerjaanya, meningkatkan kemampuan untuk melaksanakan seluruh tugas teknis yang menjadi tanggung jawabnya, meningkatkan kemampuan untuk melaksanakan seluruh tugas manajerial yang menjadi tanggung jawabnya, meningkatkan kemampuan untuk mengarahkan mitra kerja dalam melaksanakan pekerjaan dan meningkatkan kemampuan untuk membimbing Pegawai lain dalam melaksanakan tugasnya.

2. Organisasi perangkat daerah di Kabupaten Lombok Timur harus terus memberikan semangat kepada para pegawai bagian keuangan, hal ini penting untuk dilakukan karena kategori motivasi yang dimiliki oleh para pegawai bagian keuangan di organisasi perangkat daerah telah berada pada kategori tinggi, untuk itu pemberian semangat, perhatian dari pimpinan serta keakraban di antara sesame pegawai perlu untuk dipertahankan agar motivasi yang sudah tinggi dapat terpelihara.

3. Dukungan organisasi yang diberikan oleh organisasi perangkat daerah Kabupaten Lombok Timur telah berdasarkan tanggapan responden pegawai bagian keuangan di organisasi perangkat daerah telah berada pada kategori mendukung, untuk itu masingmasing instansi tempat para pegawai bagian keuangan bekerja perlu untuk 
mempertahankan dukungan yang diberikan, seperti memberikan kesempatan untuk mengikuti pelatihan, memberikan kesempatan untuk dipromosikan dan tetap memperhatikan lingkungan kerja dari para pegawai bagian keuangan di organisasi perangkat daerah Kabupaten Lombok Timur.

4. Kinerja dari para pegawai bagian keuangan di organisasi perangkat daerah telah berada pada kategori tinggi, namun terdapat beberapa hal yang perlu untuk ditingkatkan seperti inisiatif dari pegawai untuk mengerjakan pekerjaan tanpa harus menunggu di perintah oleh atasan dan berani mengambil keputusan yang memang sesuai dengan tugas pokok dan fungsinya

\subsection{Keterbatasan Penelitian}

Penelitian ini dimaksudkan untuk menguji pengaruh kompetensi, motivasi dan dukungan organisasi terhadap kinerja pegawai bagian keuangan di organisasi perangkat daerah Kabupaten Lombok Timur. Meskipun hasil penelitian ini dapat memberikan gambaran tentang pengaruh tersebut, namun masih banyak terdapat keterbatasan di dalamnya, diantaranya bahwa penelitian ini hanya mengambil responden bagian keuangan saja, menggunakan alat analisis regresi linier berganda, dan hanya menguji variabel kompetensi, motivasi dan dukungan organisasi, sedangkan masih banyak variabel lainnya yang dapat mempengaruhi kinerja seperti kepuasan, kompensasi dan pengembangan karir, sehingga perlu dilakukan pengujian kinerja dengan menambahkan variabel lainnya atau kombinasi variabel yang berbeda sehingga didapatkan hasil yang lebih komprehensif

\section{DAFTAR PUSTAKA}

Arie, Harliman, Lorens. 2007. Pengaruh Motivasi, Kemampuan dan Kepuasan kerja terhadap kinerja Pegawai pada PT Multi Structure Sarana.

Dessler. Gary, 2006. Manajemen Sumber Daya Manusia. Edisi ke sepuluh. PT. Intan Sejati. Klaten.

Endang. Ilyas. 2011. Pengaruh Kompensasi, Promosi dan Shift Kerja terhadap Kepuasan Kerja dan Kinerja Pengumpul Tol Gerbang Karang Tengah dan Ramp. Kebun Jeruk

Gibson, 1998. Fundamental of Management. $10^{\text {th }}$ Edition Mc Grow Hill

Gibson, Ivancevich dan Donnely, 2004. Organisasi . PT Erlangga, Jakarta.

Gomes, 2000. Manajemen Sumber daya Manusia . Andi Ofset, Yogyakarta

Gordon, Anderson. 1992. Managing Performance Appraisal System . UK. Strathclyde Business school.

Gouzali Saydan, 2000. Manajemen Sumber daya Manusia . DjambatanSTIM YKPN

Hadi. Agung. 2007. Kompetensi, Motivasi, peran Kepemimpinan, dan Kinerja pegawai Direktorat jenderal Perdagangan Dalam Negeri.

Hani. Handoko. 2003. Manajemen Sumber Daya Manusia. Salemba Empat. Jakarta

Hasibuan, Malayu, 2003. Manajemen Sumber Daya Manusia . PT Erlangga, Jakarta.

Hasibuan, M. 2004. Manajemen Sumber Daya Manusia. Bumi Aksara, Jakarta.

Hasibuan, Malayu. 2007. Organisasi dan Motivasi. PT. Bumi Aksara, Jakarta.

Husein Umar, 2002. Metode Riset Bisnis, PT. Gramedia Pustaka Utama, Jakarta.

John M. Echols dan Hasan Shadily,1975. An English-Indonesian Dictionary. Cornell University Press, New York 14850. Edisi bahasa Indonesia, 1996. PT Gramedia Pusaka Utama. Jakarta.

Kuncoro, M, (2007), Metode Kuantitatif, Yogyakarta : Unit Penerbit dan Percetakan (UPP) 


\section{$J M M$ UNRAM

Mangkunegara, 2005. Manajemen Sumber daya Manusia dan Perusahaan. Roasdakarya. Bandung.

Mangkuprawira, Tb. Sjafri. 2009. Bisnis, Manajemen, dan Sumberdaya Manusia. IPB Press, Bogor

Malthis. Jackson. 2000. Manajemen Sumber Daya Manusia. Salemba Empat. Jakarta

Malthis,R.L. dan Jacson,2001.Manajemen Sumber Daya Manusia, Salemba Empat, Jakarta.

Malthis and Jakson, 2003. Human Resource Management . Australia - South-Western.

Stonner, James, 1996. Manajemen . PT. Prenhallindo, Jakarta.

Mondy Wayne. R., 2008. Manajemen Sumber Daya Manusia untuk Perusahaan Rajawali Pers. Jakarta.

M. Manulang, 1994. Manajemen Personalia. Ghalia Indonesia, Jakarta.

Notoatmodjo, Soekidjo. 2009. Pengembangan Sumber Daya Manusia. PT. Rineka Cipta Jakarta:

Panggabean. Mutiara.S. 2002. Manajemen Sumber Daya Manusia. Ghalia Indonesia. Jakarta

Rampesad, Hubert K., 2006. Pertajam Kompetensi Anda dengan Personal Balance Scorecard. Sinergikan Ambisi Pribadi dengan Ambisi Perusahaan Anda. PPM. Jakarta.

Rivai, Veithzal, 2004. Manajemen Sumber Daya Manusia Untuk Perusahaan,

PT. Rajagrafindo Persada, Jakarta.

Robbins, Stephen, P. dan Mary Coulter, 2005. Manajemen, PT Indeks Kelompok Gramedia, Jakarta.

Ruky. Achmad S., 2006. Sumber Daya Manusia yang Berkualitas mengubah Visi menjadi Realitas . PT. Gramedia Pustaka Utama. Jakarta.

Sdm.blocspot.com/..efisiensi-tujuan-teknik.html. Diposkan oleh Download di jurnal Denny Bagus tanggal 2 Mei 2017.

Sedarmayanti, 2001. Sumber daya Manusia dan Produktivitas Kerja. Cv. Mandar maju. Bandung.

Siagian, Sondang. P. 2002. Kiat Meningkatkan Produktiofitas Kerja. PT. Rineka Cipta, Jakarta.

Simamora. H. 2004. Manajemen Sumber Daya Manusia. STIE YKPN. Jakarta

Sinulingga Hermanto. 2004. Pengaruh Motivasi, Kemampuan dan Kepemimpinan terhadap kinerja pegawai.

Soeharyo, S. dan Sofia, 2001. Etika Kepemimpinan Aparatur. Bahan Ajar Diklatpim Tingkat IV. Lembaga Administrasi Negara R.I. Jakarta.

Stoner. James, dan Gilbert. 2003. Manajemen. PT Indeks Gramedia Group, Jakarta.

Sudiyanto, 2008. Pengaruh Suvervisi, Pendidikan dan Pelatihan,Serta Partisipasi Dalam Kelompok Kerja Guru Terhadap Profesional Guru Sekolah Dasar di Kecamatan Semarang Utara Kota Semarang. Tesis

Suwatno dan Priansa, Donni Juni. 2011.

Veithzal. Rivai dan Ella. Jauvani. 2010, Manajemen Sumber Daya Manusia untuk Perusahaan. PT. Raja Grafindo Persada, Jakarta.

Wibowo, 2007. Manajemen Kinerja. PT. Grafindo Persada. Jakarta. 